\title{
The birth of enlightenment secularism from the spirit of Confucianism
}

\section{Dawid Rogacz}

To cite this article: Dawid Rogacz (2018): The birth of enlightenment secularism from the spirit of Confucianism, Asian Philosophy, DOI: 10.1080/09552367.2018.1428051

To link to this article: https://doi.org/10.1080/09552367.2018.1428051

册Published online: 18 Jan 2018.

Submit your article to this journal $\llbracket$

Q View related articles $\sqsubset$

View Crossmark data \lceil 


\title{
The birth of enlightenment secularism from the spirit of Confucianism
}

\author{
Dawid Rogacz \\ Department of Philosophy, Adam Mickiewicz University, Poznan, Poland
}

\begin{abstract}
The aim of the essay is to demonstrate that the contact of European philosophy with Chinese thought in the second half of the 17th and 18th century influenced the rise and development of secularism, which became a distinctive feature of the Western Enlightenment. The first part examines how knowing the history of China and Confucian ethics has questioned biblical chronology and undermined faith as a necessary condition of morality. These allegations were afterwards countered by reinterpreting Confucianism as cryptomonotheism. I will argue this debate has contributed to the birth of secular philosophy of history, which put an end to the Enlightenment Sinophilism. Throughout those changes in the image of China, nothing but an image was discussed: as it would be presented on a basis of the thought of Wang Fuzhi and other representatives of Chinese kaozheng考證 movement, the encounter with the contemporaries of the Westerners would have opened a real dialogue.
\end{abstract}

\section{KEYWORDS}

Enlightenment; secularism; Confucianism; philosophy of history; Chinese

historiography

\section{Introduction}

The aim of the essay is to demonstrate that the contact of European philosophy with Chinese thought in the second half of the 17th and 18th century influenced the rise and development of secularism, which became a distinctive feature of the Western Enlightenment. The role of internal factors that have led to the rise of the Enlightenment will be here suspended by virtue of some sort of idealization, in order to give saliency to external factors, which are quite often omitted. As John Marenbon states, in the field of intellectual history, the discovery of China in the 17th century was no less important for the inception of modern Europe than discovery of America in the 16th century (Marenbon, 2015, p. 259). Forgetting about it, 'we strengthen the illusion that European thought is a causa sui, growing up of itself, without interaction with the rest of the world. This illusion of an independent Europe allows for easy distinctions between "us" and "them," "East" and "West," at the same time that it obscures the historicity of those distinctions.' (Perkins, 2004, p. x). In the case of such notion as secularism, this illusion is even stronger.

Secularism may be defined as a belief that science cannot be limited by the need to justify itself in religious terms, it is necessary to recognize the separation of the church from the state in public life and to act according to moral norms independent from

CONTACT Dawid Rogacz dawid.rogacz@amu.edu.pl E Department of Philosophy, Faculty of Social Sciences, Adam Mickiewicz University, Szamarzewskiego 89C, 60-568 Poznan, Poland 
religious beliefs. Such secularism is itself a product of secularization, understood as either factual or necessary historical process. In the second sense it already assumes some form of philosophy of history and thus could be treated as a result of the secularization in the first sense, or precisely-as Karl Löwith famously claimed-of a 'terrestrialization' of Christian eschatology (Löwith, 1949, p. 5). The main weakness of Löwith's approach is nevertheless limitation to internal causes of secularization, which actually do not explain why some religious ideas have been terrestrialized. For that purpose, European minds have had to encounter remote and new terra firma.

\section{Secular chronology}

Chinese culture has emerged on the horizon of European thought thanks to the Jesuits. As fate turned out, its reception undermined the Christian image of the world. This occurred primarily in the field of two spheres of culture: the first was history, the second was ethics.

First and foremost, knowing the Chinese chronology cast doubt on chronology based on the Bible. In 1659 Jesuit Martino Martini published the History of China to the beginning of our era. Martini began the chronology of China with the emperor $\mathrm{Fu} \mathrm{Xi,}$ i.e. in 2952 BC, presenting the history of seven Chinese emperors who were to rule before the times widely accepted as a date of the biblical flood, 2349 BC. As if that were not enough, Martini admitted 'he takes for granted that Far Asia was inhabited long before the flood' (Martini, 1658, p. 21). The initial reaction to the shock caused by Martini's work was the rejection of the authenticity of Chinese chronology, yet Chinese records became quickly considered rather credible, and therefore reinterpreted. One of the solutions was to reconcile the Chinese chronology with the Bible. This task was undertaken by Georg Horn in his Noah's Ark from 1666. He stated that the Chinese legends about the emperors who dealt with the outflow of rivers describe the flood during Emperor Yao's reign, that is between 2355 and 2255 BC. Yao was considered a designation for Noah, $\mathrm{Fu} \mathrm{Xi-for} \mathrm{Adam} \mathrm{(Horn} \mathrm{referred} \mathrm{to} \mathrm{the} \mathrm{legend} \mathrm{that} \mathrm{Fu} \mathrm{Xi} \mathrm{had} \mathrm{no}$ father or mother), and other emperors for e.g. Cain or Enoch. Existence of the traditions preceding the Deluvium Horn explained with the fact the inhabitants of the ark laid the traditions in (van Kley, 1971, pp. 364-365). Both biblical history and Chinese historiography depicted, albeit in different ways, one and the same past. In 1669, John Webb defended the hypothesis that mankind was using the Chinese language before the Deluvium, pointing to its figurative character and the fact that the modern Chinese use the same characters as the ancient emperors (Webb, 1669). In similar manner other contemporaneous scholars demonstrated similarities between Chinese and Hebrew languages, not without manipulating the data (Duyvendak, 1936, pp. 332-340).

Martini's discovery also caused quite opposite reactions. Chinese chronology reached out to the so-called Pre-adamism, the movement that asserted the existence of people before Adam. The creator of its classic form, Isaac La Peyrère (1596-1676), in the PraeAdamitae from 1655 claimed that God has created men twice: first he created the pagans, and then created Adam, who gave rise to the Hebrews. His conclusions were supported by the exegesis of the Bible, but over time it was Chinese chronology that provided the empirical argument for the Pre-adamits (Poole, 2004, p. 3). A different viewpoint was considered by Isaac Vossius. In 1659 Isaac Vossius published de vera aetate mundi, where he stated that the chronology of the Chinese is reliable, and the 
Chinese literary tradition is the oldest in the world, covering 4,500 years, that is writers elder than Moses (Vossius, 1659, pp. 44-45). Vossius stated that in comparison with Chinese records, the dates of the Hebrew Bible are wrong. This led him to the undermining of the infallible and inspired nature of the Bible: 'Does anyone have such deficits in the judgment to believe that God always stood next to a Jewish writer and controlled his hand and pen?' (Vossius, 1659, p. 5). As a result, Vossius recognized the flood as a local event that happened only to the Jews (Vossius, 1659, pp. 53-54). However, he did not deny the facticity of the Deluvium or the truth of biblical history as such, but believed that the Septuagint, according to which the flood occurred around 3000 BC, presents chronology in line with traditional Chinese historiography, that is authentically. The step towards discrediting the revelation was nonetheless done: biblical events were deemed local, secular chronology - the criterion of the truth of the 'holy' one, and the Bible itself-not altogether divinely inspired work of fallible people, at the same level as Chinese works.

This was accompanied by a specific Sinophilism, monumental expression of which was Vossius' Book of various observations from 1685. In the chapter, 'On the magnitude of Chinese cities,' Vossius treated China as an incarnation of the Platonic project of the republic ruled by philosophers, i.e. the noble literati (the Confucians). He also wrote that the Chinese lived for thousands of years without any contact with other countries, free from war and happy until the invasion of the Tatars (Vossius, 1685, pp. 57-58; Weststeijn, 2012, p. 209). In the next chapter, 'On the arts and sciences of China,' Vossius called the Chinese language the oldest and most complete language of humanity, guaranteeing the continuity of Chinese culture throughout thousands of years (Vossius, 1685, pp. 69-70). On the following pages he celebrated Chinese accomplishments in the fields of medicine, botany, pharmacology, architecture, music, painting, sculpture, and Chinese inventions: compass, print, and dust. Only in the field of mathematics and astronomy the Christians towered about the Chinese (Vossius, 1685, pp. 70-85). The Christian heritage was relativized once again.

\section{Secular morality}

Just like in the case of the chronology, the first descriptions of the Chinese moral code came from the Jesuits. There emerged a picture of moral teachings harmonizing family, social and political life in a rational way, devoid of religious elements. In 1688, in the work La Morale de Confucius philosophe de La China, its likely author, Jean de Labrune, stated that:

It might be said that morality of this philosopher is infinitely sublime, yet still simple, reasonable, and derived from the purest sources of natural reason. Surely, never had a mind devoid of the light of God's revelation appear such developed and with such force (...) which is a very significant advantage [of this philosophy] not only over many pagan writers, who dealt with similar material, but also over some Christian authors. (Labrune, 1688, p. 4)

Confucian morality was for Labrune an ultimate achievement of human reason in the field of morality, a concrete historical experiment showing how Western morality would look like if it had not become Christian. It seemed that Chinese morality is practically equal to Christian, which later posed a question: does Christianity make people better? 
Recognition of Chinese morality has spread. According to William Temple, the philosophy of Confucius aimed at study and development of natural reasoning to its limits. As Temple wrote, according to Confucius, the highest happiness of all humanity lies in the perfection of natural reason (Temple, 1963, pp. 113-114). Nicolas Fréret claimed that Confucius' thought was full of clues that would make it possible for all humanity to be happy, and that Confucian morality should therefore be universally practiced (i.e. universalized). As Jonathan Israel notices, the philosophy of Confucius was treated as a model for all mankind mainly because it shaped and preserved Chinese culture in an unchanged millennium (Israel, 2006, p. 642).

Pierre Bayle made the next step in the interpretation of Chinese morality. While Labrune and Temple characterized it essentially as local (and Fréret as a universal) agnostic morality, the deist and defender of atheism Bayle went even further, treating Confucianism as universal atheistic morality. As he noticed:

But nothing will be more irritating than the question of the atheism of Chinese philosophers. This is not a simple negative atheism, as of the American Indians; it is a positive atheism, because [created by] philosophers by comparing the whole system based on the existence of God with the opposite system. (Bayle, 1707, p. 140)

The positivity of Chinese atheism meant both his philosophical character and opposition to mere ignorance and its moral implications. Bayle proclaimed Chinese atheism is an Asian Spinozism that recognizes the existence of one substance-nature. He argued that Spinozists and Chinese literati are aware of the moral principles and the various types of social goods no less than the most pious Christians (Bayle, 1707, p. 434). He also wrote that China is a proof that in an atheistic society there may be moral order, and even such that it is superior to Christian (see Israel, 2006, p. 646). It should be stressed that for the contemporaries of Bayle, the very expression of 'atheistic morality' was contradictio in terminis. In A Letter concerning toleration from 1689, John Locke condemned the atheists as unworthy of tolerance because of their immorality. Discussions whether morality without any (not necessarily strictly religious) belief in God is possible turned out to be pointless when such morality was not only possible but also factual.

Bayle proved to be the true winner of the debate on Chinese morality, because even Bayle's opponents, more or less consciously, accepted his image of ethics and, more broadly, Confucian philosophy (identified with Chinese in general). Dialogue between a Christian philosopher and a Chinese philosopher on the existence and nature of God by Nicolas Malebranche could serve as an example. Malebranche brought the Chinese under materialism, according to which the mind is nothing but an organized subtle form of matter (Malebranche, 1708, p. 21). Likewise, the principle (li 理) of Chinese metaphysics is inseparable from matter ( $q$ i 氣), which contradicts in his view the freedom of will. Both mistakes stem from the misunderstanding of the fact that matter is passive, as Malebranche takes for granted in his version of the Cartesian dualism (Malebranche, 1708, pp. 3, 13). This argument was to show that in Chinese thought there is no room for morality, because its condition is freedom, excluded here by materialistic determinism. As one of the few at this time, Malebranche also notes that the enlightened views of the elite must be clearly distinguished from the idolatrous religion of the rest of society (Mungello, 1980, p. 560).

Both Bayle and Malebranche regarded the Chinese as atheists, judging it differently. Malebranche wanted to persuade the Chinese to 'try' to understand Christian God under 
the notion of $l i$, with all the consequences (such as abandoning the eternity of matter) (Lai, 1985, pp. 151-178; Reihman, 2013, pp. 272-274). This interpretation, already not counterfactually, was developed by the Jesuits and Leibniz (Reihman, 2015, pp. 846-868).

\section{Counter-secular reinterpretations}

The Jesuits, from whom the controversy began, faced the need to come forth with Chinese thought in a way that would not undermine Christian truths.

One of the first Jesuits in China, Nicolas Trigault (1577-1628), spoke of Confucius as a philosopher superior to the pagans, and regarded Confucianism itself as monotheism devoid of priesthood and dogma, where the only mediator between heaven and earth was the emperor. As Rowbotham notes, this interpretation of Confucianism as a deism within the framework of charitable despotism continued until the nineteenth century (Rowbotham, 1945, p. 225). Another Jesuit, Alvarez Semedo (1585-1658), in Imperio de La China translated main Confucian virtue rèn as equally 'compassion' (Compasion), 'humanity' (Humanidad), and 'piety' (Piedad) (Semedo, 1642, p. 192). He also states that Confucianism, which is a religion older than Confucius itself (what is actually true, if only interpret 'school of scholars' rujia 儒家 as a religion), is without churches and priests, and worships the supreme being, neither describing it, nor comparing with other beings. What is more, Confucians do not expect or pray for afterlife (Semedo, 1642, p. 86).

In 1687, Philippe Couplet published in Paris the work entitled Confucius sinarum philosophus, the translation of three basic works of Confucian ethics: the Analects (Lunyu 論語), Great Learning (Daxue 大學), and Doctrine of the Mean (Zhongyong 中庸). In practice, it was much more than a translation: Couplet tried to translate these works to show the common core of Confucianism and Christianity, for example, the phrase 'who offends against Heaven' as 'who sins against Heaven' (Meynard, 2015, p. 166). Couplet's comment also synchronizes China's history with sacred history and, in a sense, the world history, e.g. 'Yi Yin decided to open goldmines in order to relieve the people who had been greatly afflicted by poor harvests and hunger for seven years there, in Egypt, and on all of earth (as the Bible attests)' (Meynard, 2015, p. 388). In a similar vein, he tried to treat the Chinese golden age as a state before the original sin (Meynard, 2015, p. 424). The compromise solution of the Jesuits was to show that Chinese morality and chronology are secular, in fact the perfect product of the natural reason, but nevertheless provide a confirmation of both moral and historical validity of the Revelation. Yet even Couplet was not consistent with the thesis that God has spoken only to the Hebrews (since according to Confucius Heaven does not speak), claiming elsewhere that knowledge of God has been revealed to the Chinese (Marenbon, 2015, p. 262).

However, the irenicon and ambivalence of the Jesuit solution, made the interpretation of Chinese thought possible to develop further in two opposing directions. One of them was to recognize the secular: if Chinese have discovered the truth immanent in the cosmos and history itself, revelation is unnecessary to know the world, but that would have deepened secularization (Meynard, 2015, p. 522). Others could have still coordinated both chronologies in the style of Horn, wondering who was, for example, the Chinese Samson, and in the field of morality continue to 'theologize' ethics, as in the case of Simon Foucher, who compared Confucius to St. Paul, stating that the first (independently of the other) acknowledged the truth about original sin (Foucher, 1688). Couplet followed Martini's chronology and dated Deluvium, just like Horn, at the reign of emperor Yao, at 
the same time defending the reliability of Chinese sources. Couplet's Tabula Chronologica, published with the Confucius sinarum philosophus, presented a continuous lineage of succession in China from 2952 BC to 1683 (Heyndrickx, 1990, pp. 192-197).

Due the efforts of the Jesuits also the Chinese neophytes, such as Li Zhizao (1565-1630) (Yu, 2011), undertook the task of according chronologies. Li Zhizao and Portuguese Jesuit Francisco Furtado are authors of the unprecedented translation of Aristotle's Categories into Chinese, published in 1631 under the title Investigation of the Theory of Names (Minglitan 名理探). In the section devoted to Aristotle's biography it is said that the Stagirite was born '381 years before the descent and birth of the Lord,' i.e. '96 years after the death of Confucius, on the year jihai, the twentieth year of the reign of King Zhou dynasty' (Li \& Furtado, 1965, p. 20). ${ }^{1}$ In this short statement, attempts were made to agree upon four different chronologies: (1) Christian, (2) classical dynastic chronology, (3) traditional cyclical chronology (jihai is 36th year in the sexagenary cycle), and (4) chronology counted from the death of Confucius. Interestingly, the latter has never been used before: it was created here by analogy to a Christian, linear vision of history. Synchronization of these chronologies, and even more: reconciliation of cyclic and linear visions of time, may be treated as an anticipation, or even an important factor contributing to the concept of world history.

The greatest adherent of the 'Jesuit option' was Gottfried Wilhelm Leibniz, who openly admitted to being its supporter (Lach, 1945, p. 447). Genuine interest and inspiration from Chinese philosophy made their mark in many places of the Leibniz' system, even in the scientific debate with Clark (Ribas, 2003). Leibniz noticed the similarity between his 'universal arithmetic,' that is the binary code, and trigrams coming from the Book of Changes (Yijing 易經). In the dissertation An explanation of binary arithmetic from 1703, Leibniz emphasizes that the Chinese 'forgot' original meaning of the trigrams, understanding them metaphysically, therefore, their pristine sense should be restored: an artificial language should be recreated (Leibniz \& Wolff, 1992, p. 85; see Aiton, 1985, pp. 245-248).

One of Leibniz's first mentions of China is a letter to father Grimaldi in 1692, where he refers to the chronology controversy: he deems the Chinese outstanding in history and politics, but insists that burning of the books commissioned by the first Chinese emperor does not allow to assess the credibility of the transmitted texts (Leibniz \& Wolff, 1992, p. 65). In 1697, Leibniz wrote Novissima Sinica, essentially repeating most of the Jesuit messages concerning China. In the preface to this work Leibniz celebrates the emperor Kangxi as a wise, just, and tolerant for Christians philosopher who embodies the Platonic ideal (Riley, 1999, p. 229). The Chinese themselves were said to have an aversion to war and to better Europeans in the field of morality, living almost as if guided by Christ. Leibniz stressed that virtue of the Chinese as completely mundane was not complete: they would need Christianity to make it perfect (Riley, 1999, pp. 230-231). Leibniz did not ask, however, how it is possible that Europeans with their faith in Christ give place to unbelieving Chinese. As a result, he also did not know why the Chinese were moral at all. Hence, as Perkins points out, even though it was not Leibniz's intention, his idealization of China was a step toward deepening of deism (Perkins, 2002, p. 454): it gave the field to the naturalistic ethics. It is no accident that Samuel von Pufendorf supported his theory of natural law by the example of China: the foundation of Chinese law was not a contract or a religion but a belief in the goodness of human nature (Fuchs, 2006, p. 42). 
Leibniz' attitude towards the Yijing and Chinese ethics was a part of his overall strategy of interpretation of Chinese culture. In a short On the Civil Cult of Confucius (1700), he states:

Nor is it absurd that European intellectuals like Ricci should see what may not have been sufficiently noted by the Chinese scholars, and should interpret their ancient books better than they could themselves. Who today does not know that the Christian scholars are much better interpreters of the ancient books of the Hebrews than the Jews themselves are? Do not outsiders very often discern the history and records of a people better than its own citizens? (Leibniz \& Wolff, 1992, p. 79)

Hence, Leibniz openly adopts the ethnocentric and inclusivist position (Jones, 2014, pp. 78-79; cf. Nelson, 2009, pp. 277-300). It is worthy to note that attempts to transfer monadology to the theory of history, made by Ankersmit (1983, pp. 135-142), are not supported by Leibniz' views on this issue: Europe has privileged access to the inner life of Chinese monads. Those assumptions were practically realized in Discours sur La Théologie naturelle Des Chinois from 1716. As the title indicates, according to Leibniz, the Chinese were not atheists, but rather the followers of a specific natural theology. Interestingly, Leibniz does not treat Heaven as equivalent category for God, but rather Neo-Confucian concept of the principle of things li 理(calling it inteligentia supramundana). Its opposite, matter qi氣, says Leibniz, is indeed said to be eternal, but the Chinese nowhere claim that it has no beginning, because this truth (creatio ex nihilo) can be grasped only due to Revelation (Leibniz \& Wolff, 1992, pp. 89, 92, 106). Later Leibniz discusses other dogmas, such as immortality of the soul. Undoubtedly, the manipulation of Chinese sources did not seek to understand them. Also, it was not only a rejection of the 'atheistic' image of Chinese thought: it rather showed that all cultures share one truth (Li \& Poser, 2006, p. 28).

How did Leibniz's attitude lead to further secularization? Before the suppression of the Jesuits, on 18 October 1700, the Sorbonne theologians condemned the following theses:

(1) The Chinese have preserved knowledge of the true God from more than two thousand years before the birth of Jesus Christ.

(2) They have had the honor to sacrifice to Him in the most ancient temple in the universe.

(3) They have honored Him in a manner that can serve as an example even to Christians.

(4) They have practiced a morality as pure as their religion.

(5) They have had the faith, humility, interior and exterior worship, priesthood, sacrifices, saintliness, miracles, the spirit of God, and the purest charity, which is the character and the perfection of true religion.

(6) Of all the nations of the earth, the Chinese have been the most constantly favored by the grace of God (Perkins, 2004, p. 30).

The condemnation of these theses again made the Chinese pagans. And if the Jesuit interpretation was officially rejected, only the 'atheist' remained. In this way, the Jesuits once again-indirectly and completely unintentionally-contributed to the stimulation of the emerging secularism. This is well illustrated by Wolff, who was close to Leibniz as a philosopher, but differed greatly in the interpretation of Chinese thought. 
In the Discourse on the practical philosophy of the Chinese from 1721 (footnotes from 1726) Wolff writes that the Chinese have the same relationship to Confucius as the Jews to Moses, the Turks to Mohammed, and the Christians to Christ. The first three nations, however, do not know the 'savior of the world and the order of eternal salvation,' so only in a comparison they are put on the same level (Leibniz \& Wolff, 1992, pp. 155-156; R. Weber, 2014, p. 152). Wolff cuts away from Leibniz's inclusivism, while at the same time laying down the foundations for comparative studies of religions that (despite his view on the superiority of Christianity) partially secularize Christianity, treating it, as for the structure, as a phenomenon similar to the other religions. This idea of the great founders initiating in the same time parallel ways of historical development will be taken up in the twentieth century by Karl Jaspers (Jaspers, 1953, pp. 11, 27). Moreover, Wolff claims that China's principle of morality was not to oppose nature, and this ethics had nothing to do with the natural, or the more revealed religion. One cannot even suppose, Wolff argues, the Chinese were atheists, because to become an atheist one must have some concept or image of God (Leibniz \& Wolff, 1992, pp. 162-164). He further idealizes Confucian morality, considering the Chinese as the most virtuous and educated in virtue, and in the work On the philosopher king, he also referred to politics by repeating the eulogies about Chinese philosopher kings. Wolff's thesis caused indignation in Europe, because they implied the atheists were not so much equally but even more moral than the believers (Lach, 1953, p. 571).

\section{China and the birth of secular philosophy of history}

The problems brought about by the discovery of Chinese chronology were practical: they provoked the question of the credibility of the records, stimulating reflection on what makes historical source a reliable one (the reliability of the Bible dates is ensured by Revelation). If they were to be credible, they were either claimed relatively independent from biblical events or 'translated' into sacred history, by means of looking for counterparts of figures and events. The first case was embarrassing theoretically, because it led to understanding biblical events locally or even suggested the falsehood of the Bible, and consequently its secular character, at least as far as chronology was concerned. None of these points were yet a theoretical problem: China was not a part of the same historical narrative as Europe itself. Bossuet's Discours sur l'histoire universelle of 1682 are, in spite of the title, a lecture on biblical history: they begin with Adam and Eve (Bossuet, 2013, p. 12) and at the same time ignoring the history of India or China. Excluding China from the domain of the actions of Divine Providence, Bossuet also deprived them of historicity. As Löwith shows, Bossuet's Providence is an invisible and transcendent force intervening in history in a way incomprehensible for human, while according to Giambattista Vico, Providence does not control history outside of it, but manifests itself through the social history of nations in a manner understandable to everyone who has insight into the nature of the soul (Löwith, 1949, pp. 123-124, 142-143). Vico, however, supports Bossuet's duality of sacred and secular history, conferring primacy on religious order. He states the sacred history is true, and the histories of other ancient peoples are merely mythology. Secondly, 'this axiom is one of the principal reasons for the division of the entire world of the ancient nations into Hebrews and gentiles' (Vico, 1948, p. 61). 
Just as a man confined while asleep in a very small dark room, in horror of darkness [on waking] believes it certainly much larger than groping with his hands will show it to be, so, in the darkness of their chronology, the Chinese and the Egyptians have done, and the Chaldeans likewise. It is true that Father Michele Ruggieri, a Jesuit, declares that he has himself read books printed before the coming of Jesus Christ. It is true further that Father Martini, another Jesuit, in his Sinica historia ascribes a great antiquity to Confucius, which has led many into atheism, (...) Isaac de la Peyrère, author of the Preadamitae, perhaps for that reason abandoned the Catholic faith and then wrote that the flood spread over the lands of the Hebrews only (...) Confucian philosophy, like the priestly books of the Egyptians, in its few references to physical nature is crude and clumsy, and it turns almost entirely on a vulgar moral code, that is to say on morals commanded to the people by laws. (Vico, 1948, p. 30)

Vico refers both to Chinese chronology and morality, noticing that it 'has led many into atheism,' which proves the secular effect of the confrontation of European culture with the Chinese, all the more because Vico was a person unfavorable to Sinophils. Also within the internal structure of the argument, Vico needs to undermine the Chinese chronology as 'dark' and 'fabuluous': otherwise it is impossible to prove the truth of revealed history.

The gradual nature of the development of European thought and its secularization, shows, however, that it is possible to deny Vico's dualism and to deem Chinese chronology reliable, yet still remain within the perspective of the theology of history. This position was represented by... Wolff, who argued that Providence has called Confucius: 'with Confucius being born at a conjunction of time that rendered his birth necessary to prevent all the decadence of his country, one could not doubt the particular designs of Providence for this great man' (Leibniz \& Wolff, 1992, p. 153) Given the fact that these ideas were presented in the inaugural university lecture in the presence of 'thousands of students,' in response to which over 130 polemics and critical reviews were published (Lach, 1953, pp. 563, 567), and Friedrich Wilhelm himself discharged Wolff from the University of Halle, it must have had a direct impact on the visions of Voltaire and Hegel.

There is no doubt that although Wolff continued to use the term 'Providence,' it was the Providence of philosophers-beyond the biblical description and determining the history of China in response to its specific historical conditions, namely the fall of the Zhou dynasty. Bossuet's Providence was transcendent and divided mankind into pagans and believers; Vico rejected its transcendence, but retained the dualism; Wolff rejected dualism, but did not get off Providence. Only Voltaire's renouncement of Providence has opened the door to secular philosophy of history and true universalism. As Koselleck argues, one of the distinguishing features of the Enlightenment was the emergence of the notion of history (Geschichte), a collective singular that links together different histories (Koselleck, 2006, p. 74). One history expressed not only temporal but also spatial universality: it implied the idea of one humanity.

In the Encyclopedia entry 'History,' Voltaire defined history as 'a narrative of facts given as real as opposed to fiction' (le récit Des faits pour donnés vrais, au contraire de La fable). Then he distinguished sacred history from the secular (sacrée \& profane), noting he will not deal with the first. Asking where to find secular history, Voltaire indicates Herodotus and Chinese chronicles (Voltaire, 1765, pp. 220-222). Chinese historiography is not only primeval and continuous, but also indisputably reliable. What appealed to him the most was, however, that almost all Chinese records of the origins of the state are natural and probable, dispensing with the gods and miracles, in stark contrast to the 
legends in the rest of the world (Sakmann, 1971, p. 30). For Voltaire, China was a model of the secular universal history, which in the preface to his groundbreaking Essay on Universal History, the Manners, and Spirit of Nations from 1756 was named for the first time with the term 'philosophy of history.' As he noticed, Bossuet intentionally omitted China in the universal history (Voltaire, 1759, p. 3). Voltaire begins his history just with China, what would be typical for subsequent philosophy of history. The rationale for this decision was not only that the Chinese are the oldest nation in the world, but also that this consecution reflects the order of civilizing the nations of the world. The epitome of the spirit of China was Confucius who gave 'the purest ideas that human nature unassisted by revelation can form of the supreme Being' (Voltaire, 1759, p. 23). He was neither Christian nor atheist, but rather a creator of deism, which surpasses superstitions of pagans and Christians. As for the Chinese regime, it is the best possible one: under the rule of the enlightened king (not a despot), the Chinese practice principles of their superior morality and 'are happy in so far as human nature is at all capable of happiness' (Voltaire, 1759, pp. 10, 23-25, 297-300). Undoubtedly, in these exaggerated statements there are not so much description of Chinese culture as Wolter's anti-clericalism and the conviction of the moral superiority of deism.

But philosophy of history, brought to life (partly) by the model of China, contained an opposite root. China was depicted as ancient, natural, and unchanged for millennia paradise without God and without sin, and therefore also without what is truly human. Philosophy of history, determined by the sequence of wars and the related progress, stood in opposition to everlasting, motionless China. Already Voltaire admitted it, writing that China had made no progress from ancient times and its inventions resulted from practical needs, not scientific development (Voltaire, 1759, pp. 19-20; see van Kley, 1971, p. 384). Another French philosopher of history and a bard of progress, Condorcet, said that China froze in a 'shameful immobility' and 'eternal mediocrity' (Blue \& Brook, 1999, p. 91). In the lectures devoted to the religions of Asia, Kant states that 'philosophy is not to be found in the whole Orient' and 'a concept of virtue and morality never fell into the heads of the Chinese' (von Glasenap, 1954, p. 104).

Herder was even more critical of China. In his Ideen zur Philosophie der Geschichte der Menschheit (1792-91), Herder ridicules European fascination with China and rejects the chronology of the Chinese before 722 BC as a childish 'dream' and mythology (Herder, 1800 , p. 270). He claims that the Chinese cannot escape their 'natural constitution,' depicting them as a crude nation originating from the Mongols, whose people are ugly and stupid (Herder, 1800, p. 293). Confucius is said to manacle the Chinese with the shackles of political morality, which stopped the development of the state at the stage of boyhood. Finally, Herder called China 'embalmed mummy painted with hieroglyphics,' confirming the turn made philosophy of history (Herder, 1800, p. 296).

From this perspective, China's position in the Hegel's philosophy of history does not bring a significant innovation. Hegel begins the philosophy of history from China, classified as despotism, which despite the changes of rulers, conflicts or invasions, is ultimately 'untouched by history' (Ungeschichtlich) (Hegel, 2011, p. 214). Moral rules in China do not result from will and conscience, they are external; and while everyone is equal, only emperor is truly free (Hegel, 2011, pp. 230-234). Despite many differences in the theory of history, Marx with the concept of Asian mode of production and its despotism, as well as Weber with the rationalization theory were Hegel's heirs. It is 
Weber who proclaimed that 'the power of logos, of defining and reasoning, has not been accessible to the Chinese' (M. Weber, 1951, p. 125) because of 'lack of a particular mentality' (M. Weber, 1951, p. 104).

\section{The secular other}

The position recognized by Malebranche and Leibniz as typical for Confucianism at their time was Zhu Xi's (朱喜, 1130-1200) conception, so in their times it had almost half a millennium. Leibniz himself admitted it by saying, 'I do not know whether one has yet sufficiently explained what the doctrine of the Chinese literati really is. [I refer] to that of the ancients, officially endorsed and supported by their classical texts' (Leibniz \& Wolff, 1992, p. 78). Also Voltaire and Hegel did not take into account anything new that Malebranche or Leibniz would not have known or even seemed to have ignored some of the sources available. Hence, the question should be asked: what concepts actually came into being in Chinese philosophy at a time when the Analects came to Europe in the second half of the 17th century? Had Europe been familiar with them, would it have corroborated the Western interpretations of Chinese philosophy or would they have challenged the emerging Enlightenment?

According to the leading philosopher of that time, Wang Fuzhi (王夫之，1619-1692), there exist only matter consisting of the opposing forces of yin 陰 and yang 陽: both earth and Heaven (Tian 天) are material (Fang, 2006, p. 111). ${ }^{2}$ Matter fills everything: there is no 'non-being' ( $w u$ 無), the matter is infinite and eternal, and the birth and death of man are only its transformations (Fang, 2006, pp. 111-114, 134-135). Also the spirit (shen 神) is only a subtle form of matter (Fang, 2006, p. 292). ${ }^{3}$ On this basis, the interpretation of Chinese philosophy as materialistic monism becomes even more legitimate.

Wang Fuzhi did not consider matter as passive material: 'for Wang, qi is not a blind force, working under the regulation of some independent higher principle. Rather, qi is regulated with its own internal logic, which he calls li' (Liu, 2010, p. 356). Another term for li, considered from a dynamic point of view, is shi 勢, 'power,' 'tendency.' Shi determines the direction of the development of things $(\mathrm{Hu}, 2006, \text { p. } 5)^{4}$ in a dialectical way, by the succession of the yin and yang forces: when yin is in the peak phase, it changes into yang, and vice versa (Liu, 2001, p. 330). These transformations of natural forces are reflected in the social sphere: they correspond to the repetitive phases of order and chaos in the world of politics (Fang, 2006, p. 527). ${ }^{5}$ As Wang Fuzhi writes, 'the tendency (shi) of the world involves disintegration and merging, order and chaos (...) In this one can recognize the essence (dao 道) of Heaven (Tian), by means of that one can know [the laws of] human politics. ${ }^{6}$ (Wang, 1994,745-746) This relation resembles historical law: 'times are changing, but the essence remains constant, the change does not lose its permanence' (Deng, 2012, p. 30). ${ }^{7}$ The tendency of history is linear (although it includes cycles of order and chaos) and irreversible. This means that the old days will not come back: 'that the old [feudalism] will not return, this is shi (Hu, 2006, p. 6). ${ }^{8}$ Shi, that is the conditions and circumstances of particular times, change with the age (Wang, 2013, p. 97). The person who can recognize these circumstances is called by Wang a 'unique individual,' that is_as Fang Litian writes-historical hero (Fang, 2006, p. 529). In general, Wang Fuzhi argues that mankind has evolved from a state of severity to the state it is able to use nature to satisfy its needs (Xiao \& Xu, 2002, p. 216). He speculates 
that the Chinese originated from the barbarians, while the first people-from bipeds who walked upright ( $\mathrm{Ng} \&$ Wang, 2005, p. 232). China should continue this process of the process of proceeding from barbarity to civilization (wen 文) in order to beat the Manchu (Xiao \& Xu, 2002, pp. 218-219). The fact the Manchu Qing dynasty claims to receive the Mandate of Heaven (Tianming 天命), shows that there never was such thing as the power given 'from on high' (Sun, 2015, p. 95).

The potential deeper encounter with the seventeenth-century Chinese philosophy could have contributed to rethinking the assumptions of the (nascent) Western philosophy of history and its immanent part, the idea of progress. It would have even been a confrontation or even a synthesis of two visions of history. In the PRC, Wang Fuzhi is treated as a pre-Marxist historical materialist. Young Mao Zedong (born in the same province as Wang, in Hunan), attended lectures conducted by the Wang Fuzhi Institute. Mao expressed direct appreciation for his 'materialism and nationalism' (Platt, 2007, p. 184). It can only be speculated what effect would Europe have had with these ideas more than a centuries before Marx.

However, the thought of Wang Fuzhi should be framed within the broader context of the 'source criticism' movement (kaozhengxue考證學), which reformulated the heritage of Chinese culture through historical and philological research. For instance, Wan Sitong (1638-1702) explained the fall of the Ming dynasty using economic categories. He claimed that historian should use credible sources, establish facts and refrain from judging them (Ng \& Wang, 2005, p. 228). The methods of historical criticism were also applied to the Confucian canon, undermining its authorship or authenticity: the canon became historicized. The emblematic expression of this idea was given by Zhang Xuecheng (1735-1801): 'all six classics are histories' (Liujing jie shi ye六經皆史也) (Zhang, 2012, p. 2). Zhang believed the Confucian Canon, like all other historical works, is a part of literature. It should be interpreted with 'sympathy' (shu 恕), that is understood in what historical conditions they were created. Yet Zhang did not believe any objectivity was possible in this regard, because the reading of these works is also conditioned by the historical conditions and, as he put it, 'the morality of the historian' (shide 史德), the system of values shared by him (Zhang, 2012, pp. 309-323; see Ivanhoe, 2009).

Just like historiography, also traditional view on politics received criticism. Huang Zongxi (1610-1695) condemned autocracy, declaring that power belongs to the people, and the emperor cannot rule not taking public opinion (gonglun公論) into account (Struve, 1988, pp. 475-476). Huang also suggests that the ruler should establish a basic law that will limit the power (Huang, 1993, p. 91). It was therefore a proposal to establish a constitutional monarchy in the republican spirit. Also social demands, such as the appeal for the universal education of women by Cheng Hongmou (1696-1771), were added to the political proposals (Chen, 2000, p. 162).

As a result, Benjamin Elman claims that the Qing Dynasty Confucians effectuated secularization similar to that of the West (Elman, 2001, p. 6). Michael Quirin believes such interpretations are wrong, because there was nothing to secularize: the Confucian canon never had the status of revealed scriptures, and the Christian opposition of theology and history was alien to the Confucians (Quirin, 1996, pp. 45-46). Also the definition of the kaozheng movement as 'enlightenment' (qimeng 启蒙), like in Gao Jianlong's work comparing the kaozheng with 17th-century Puritanism (Gao, 2014), is precipitant. If enlightenment would mean in this context the emergence of a worldview opposed to 
the traditional value system, which rejected the status of canonical works of the past, such enlightenment took place in China only in 1919, during the Fourth May Movement.

In all fairness it should be noted that not only the Europeans but also the Chinese themselves were not interested in the deepening dialogue between the East and the West. Wang Fuzhi was interested in Western astronomy and physical experiments, but regarded them as plagiarisms of the Chinese concepts. He denounced Christianity for putting the love of God over the love of parents and called Matteo Ricci 'a barbarian' (Tan, 2010, pp. 340-341). The critique of the West was fully expressed in Yang Guangxian's essay from 1665 titled I cannot do otherwise (Budeyi 不得已), which criticized treating Confucian works as written by Christian barbarians (Yang, 2000, pp. 151-152).

\section{Conclusion}

The contact with Chinese culture meant for seventeenth-century Europe a contact with secular chronology and morality. The earliest Sinophils expressed the idea that the revealed history may be only local (Vossius), and Christian morality is only one of the many available (Labrune). In addition, since Western ethics was rooted in both faith and understanding, and the Chinese only in the latter, it was Confucian ethics that deserved a universal status. Later, Confucianism became synonymous with rather atheistic than agnostic morality, for both sympathizers (Bayle) and the opponents of atheism (Malebranche). The Jesuits and Leibniz, searching for alternatives, argued the Chinese were deists, people who came to the knowledge of God without support of Revelation. At this moment Revelation became, as shown on the example of Wolff, superfluous, and after condemning the Jesuits, there remained only deism, whose chief expresser was Voltaire. He broke Vico's duality of sacred and secular history, and pagans and believers, recognizing Chinese historiography as a model of secular 'philosophy of history,' beginning of universal history. The vision of unchanging China, contrasted with the idea of progress, made China ultimately ahistorical and staying at the primitive stage of history. In this way the Other was finally tamed and pacified.

Last, this contact had little to do with dialogue. The best informed Malebranche and Leibniz referred to the philosophy of Zhu Xi considered to be a picture of modern Chinese culture in spite of 500 years. The philosophers of the Qing dynasty, especially Wang Fuzhi with his philosophy of history, were completely unknown to the Europeans, although they all criticized traditional Confucianism. Most of all, however, Chinese thought aroused interest only insofar as it represented known and discussed attitudes. As Mungello wrote, 'in this context of masculine Eurocentrism, Malebranche was probably motivated to write Dialogue rather because he recognized in Chinese philosophy the sign of a Spinozian enemy rather than because of any greater interest in China' (Mungello, 1980, p. 561). Europe was a monad that lacked real contact with Chinese philosophy and instead created merely its representation: the evolution of this construct was at the same time the evolution of European thought. For this reason, in my analysis internal factors were suspended, but not abolished, since they were still decisive in the rise of Enlightenment secularism. Europe, in order to protect its monadic interior life, has created a specific 'immune system' that has recognized the alien body and has destroyed it. Secularism was, perhaps not so much a target but rather a side, effect of this process. 


\section{Notes}

1. 生於天主未降生前三百八十一年。孔子歿後九十六年。周安王二十年己亥。

2. 陰陽二氣充滿太虛, 此外更無他物, 亦無間隙, 天之象, 地之形, 皆其所範圍也。

3. 天之氣伸於人物而行氣化者曰神 (...) 人之所以生即鬼神之盛, 則體驗於身而鬼神在我矣。

4. 勢之所趨, 豈非理而能然哉。

5. 治亂循環, 一陰陽動靜之幾也。

6. 天下之勢，一離一合，一治一亂而已 (...) 於此可以知天道焉, 於此可以知人治焉。

7. 時函變而道皆常, 變而不失其常。

8. 夫封建之不可複也, 勢也。

\section{Disclosure statement}

No potential conflict of interest was reported by the author.

\section{Funding}

This work was supported by the National Science Centre in Poland [Grant 2015/19/N/HS1/00977].

\section{References}

Aiton, E. (1985). Leibniz: a biography. Bristol: A. Higher.

Ankersmit, F. (1983). Narrative logic: A semantic analysis of the historian's language. The Hague: Kluwer Boston.

Bayle, P. (1707). Réponse aux questions d'un provincial (Vol. 4). Rotterdam: chez R. Leers.

Blue, G., \& Brook, T. (1999). China and historical capitalism: Genealogies of sinological knowledge. New York, NY: Cambridge University Press.

Bossuet, J.-B. (2013). Discours sur l'histoire universelle. St-Augustin, FL: Cap-Rouge.

Chen, H. (2000). On women's education. (W. Rowe, Trans.). In T. de Bary \& R. Lufrano (Ed.), Sources of Chinese tradition (Vol. II, pp. 161-162). New York, NY: Columbia University Press.

Deng, H. 邓辉. (2012). A historical characteristics of Wang Fuzhi's [notion of] Dao论王船山之“道”的 历史性特征. Chuanshan xuekan, 2, 26-30.

Duyvendak, J. (1936). Early Chinese studies in Holland. T'oung Pao, 32(1), 293-344.

Elman, B. (2001). From philosophy to philology: Intellectual and social aspects of change in late imperial China. Los Angeles, CA: University of California Press.

Fang, L. 方立天. (2006). Classical Chinese philosophy 中国古代哲学 (Vol. 1). Beijing 北京: Zhongguo Renmin Daxue chubanshe 中国人民大学出版社.

Foucher, S. (1688). Lettre sur la morale de Confucius, Philosophe de la Chine. Paris: Legrand.

Fuchs, T. (2006). The European China - receptions from Leibniz to Kant. Journal of Chinese Philosophy, 33(1), 35-49.

Gao, J. 高建龙. (2014). Heavenly way and political way: A comparative research of Chinese Confucian thought and Christianity in the seventeenth-century 天道与政道: 17世纪中国儒家思想与清教主 义对比研究. Beijing 北京: Zhongguo Shehui Kexue Chubanshe 中国社会科学出版社.

Hegel, G. W. F. (2011). Lectures on the philosophy of world history. (R. Brown \& P. Hodgson, Trans.). Oxford: Oxford University Press.

Herder, J. G. (1800). Outlines of a philosophy of the history of man. (T. Churchil, Trans.). London: Bergman Publishers.

Heyndrickx, J. (1990). Philippe couplet, s. j. (1623-1693): the man who brought china to europe. Nettetal: Steyler- Verlag.

$\mathrm{Hu}, \mathrm{F}$. 胡发贵. (2006). On the rational spirit of Wang Fuzhi's historicism论王夫之历史观的理性精神. Chuanshan xuekan, 3, 5-8. 
Huang, Z. (1993). Waiting for the dawn. A plan for the prince. (Wm Theodore de Bary, Trans.). New York, NY: Columbia University Press.

Israel, J. (2006). Enlightenment contested: Philosophy, modernity, and the emancipation of man, 1670-1752. Oxford: Oxford University Press.

Ivanhoe, P. (2009). Lessons from the past: Zhang Xuecheng and the ethical dimensions of history. Dao: A Journal of Comparatvie Philosophy, 8, 189-203.

Jaspers, K. (1953). The origin and goal of history. New Haven, CT: Yale University Press.

Jones, C. (2014). The prospects for interreligious and intercultural understanding: The Jesuit case and its theoretical implications. In P. Phan \& J. Ray (Ed.), Understanding religious pluralism: Perspectives from religious studies and theology (pp. 66-86). Eugene, OR: Pickwick Publications.

Koselleck, R. (2006). Begrifssgeschichten. Studien zur Semantik und Pragmatik der politischen und sozialen Sprache. Frankfurt am Main: Suhrkamp Verlag.

Labrune, J. (1688). La morale de Confucius philosophe de la China. Amsterdam: chez P. Savouret.

Lach, D. (1945). Leibniz and China. Journal of the History of Ideas, 6(4), 436-455.

Lach, D. (1953). The Sinophilism of Christian Wolff (1679-1754). Journal of the History of Ideas, 14 (4), 561-574.

Lai, Y.-T. (1985). The linking of Spinoza to Chinese thought by Bayle and Malebranche. Journal of the History of Philosophy, 23, 151-178.

Leibniz, G. W. F., \& Wolff, C. (1992). Moral enlightenment: Leibniz and Wolff on China. (J. Ching \& W. Oxtoby, Trans.). Nettetal: Steyler Verlag.

Li, W., \& Poser, H. (2006). Leibniz's positive view of China. Journal of Chinese Philosophy, 33(1), $17-33$

Li, Z. 李之澡, \& Furtado, F. 傅凡際. (1965). Investigation of the theory of names 名理探. Taibei 台北: Shangwu Yinshuguan商務印書館.

Liu, J.-L. (2001). Is human history predestined in Wang Fuzhi's cosmology? Journal of Chinese Philosophy, 28(3), 321-338.

Liu, J.-L. (2010). Wang Fuzhi's philosophy of principle (Li) inherent in Qi. In J. Makeham (Ed.), Dao companion to Neo-Confucian Philosophy (pp. 355-379). London: Springer.

Löwith, K. (1949). Meaning in history: The theological implications of the philosophy of history. Chicago, IL: The University of Chicago Press.

Malebranche, N. (1708). Entretien d'un philosophe chretien, et d'un philosophe chinois, sur l'existence \& la nature de Dieu. Paris: chez M. David.

Marenbon, J. (2015). Pagans and philosophers: The problem of paganism from Augustine to Leibniz. Princeton: Princeton University Press.

Martini, M. (1658). Sinicae historiae decas prima. Amsterdam: apud J. Blaeu.

Meynard, T. (2015). The Jesuit reading of Confucius: The first complete translation of the Lunyu (1687) published in the West. Leiden: Brill.

Mungello, D. (1980). Malebranche and Chinese Philosophy. Journal of the History of Ideas, 41(4), 551-578.

Nelson, E. (2009). Leibniz and China: Religion, hermeneutics, and enlightenment. Religion in the Age of Enlightenment, 1, 277-300.

Ng, O.-N., \& Wang, Q. E. (2005). Mirroring the past. The writing and use of history in imperial China. Honolulu: University of Hawai'i Press.

Perkins, F. (2002). Virtue, reason, and cultural exchange. Leibniz's praise of Chinese morality. Journal of the History of Ideas, 63(3), 447-464.

Perkins, F. (2004). Leibniz and China: A commerce of light. Cambridge: Cambridge University Press.

Platt, S. (2007). Provincial patriots: The Hunanese and Modern China. Cambridge: Harvard University Press.

Poole, W. (2004). Seventeenth-century Preadamism, and an anonymous English Preadamist. The Seventeenth Century, 19(1), 1-35.

Quirin, M. (1996). Scholarship, value, method, and hermeneutics in Kaozheng: Some reflections on Cui Shu (1740-1816) and the Confucian classics. History and Theory, 35(4), 34-53.

Reihman, G. (2013). Malebranche and Chinese Philosophy: A reconsideration. British Journal for the History of Philosophy, 21(2), 262-280. 
Reihman, G. (2015). Malebranche's influence on Leibniz's writings on China. Philosophy East and West, 65(3), 846-868.

Ribas, A. (2003). Leibniz' disclosure on the natural theology of the chinese and the leibneiz-clarke controversy. Philosophy East and West. 53(1), 64-86.

Riley, P. (1999). Leibniz's political and moral philosophy in the Novissima Sinica, 1699-1999. Journal of the History of Ideas, 60(2), 217-239.

Rowbotham, A. (1945). The impact of Confucianism on seventeenth century Europe. The Far Eastern Quarterly, 4(3), 224-242.

Sakmann, P. (1971). The problems of historical method and of philosophy of history in Voltaire [1906]. History and Theory, 11, 24-59.

Semedo, A. (1642). Imperio de la china: I cultura evangelica en èlpor los religios de la Compañia de lesus. Madrid: Impresso por I. Sanchez.

Struve, L. (1988). Huang Zongxi in context: A reappraisal of his major writings. The Journal of Asian Studies, 47, 474-502.

Sun, Q. 孙钦香. (2015). Wang Fuzhi 王夫之. Nanjing 南京: Nanjing Daxue Chubanshe南京大学出版社. Tan, M. (2010). Wang Fuzhi's interpretation of Confucian classics in a time of radical change from Ming to Qing Dynasty (Unpublished PhD thesis). University of Toronto, Toronto.

Temple, W. (1963). Five miscellaneous essays by Sir William Temple. Ann Arbor, MI: The University of Michigan Press.

van Kley, E. (1971). Europe's 'discovery' of China and the writing of world history. The American Historical Review, 76(2), 358-385.

Vico, G. (1948). The new science. (T. Bergin \& M. Fisch, Trans.). Ithaca, NY: Cornell University Press. Voltaire, F. M. (1759). An essay on universal history, the manners, and spirit of nations, from the reign of Charlemaign to the age of Lewis XIV (Vol. 1). (Mr Nugent, Trans.). London: J. Nourse.

Voltaire, F. M. (1765). Histoire. In D. Diderot (Ed.), Encyclopédie ou dictionnaire raisonné des sciences, des arts et des métiers (Vol. 8, pp. 220-222). Paris: Briasson et al.

von Glasenap, H. (1954). Kant und die Religionen des Ostens. Kitzingen-Main: Holzner-Verlag.

Vossius, I. (1659). Dissertatio de vera aetate mundi. Hagae-Comitis: ex typographia Adriani Vlacq.

Vossius, I. (1685). Variarum observationum liber. London: apud R. Scott.

Wang, F. 王夫之. (1994). The interpreting treatise on the comprehensive mirror讀通鑑論. Zhengzhou 郑州: Zhongguo Guji Chubanshe 中国古籍出版社.

Wang, F. 王夫之. (2013). The treatise on the song宋论. Beijing 北京: Zhonghua Shuju 中华书局.

Webb, J. (1669). An historical essay endeavoring a probability that the language of the empire of China is the primitive language. London: printed for N. Brook.

Weber, M. (1951). The religion of China: Confucianism and Taoism. (H. Gerth, Trans.). Glencoe, IL: The Free Press.

Weber, R. (2014). Comparative philosophy and the Tertium: Comparing what with what, and in what respect? Dao: A Journal of Comparatvie Philosophy, 13(2), 151-171.

Weststeijn, T. (2012). Vossius' Chinese utopia. In E. Jorink \& D. van Miert (Eds.), Isaac Vossius (1618-1689): Between science and scholarship (pp. 207-242). Leiden: Brill.

Xiao, S. 萧萐父, \& Xu，S. 许苏民. (2002). Critical biography of Wang Fuzhi 王夫之评传. Nanjing 南京: Nanjing Daxue Chubanshe 南京大学出版社.

Yang, G. (2000). I cannot do otherwise. (J. Young, Trans.). In T. de Bary \& R. Lufrano (Ed.), Sources of Chinese tradition (Vol. II, pp. 150-152). New York, NY: Columbia University Press.

$\mathrm{Yu}, \mathrm{L}$. (2011). The spiritual journey of an independent thinker. the conversation of li zhizao to catholicism. Journal Of World History, 22(3), 433-453. doi:10.1353/jwh.2011.0065

Zhang, X. 章学诚. (2012). Comprehensive meaning of literature and history 文史通义 (Vol. 1). Beijing 北京: Zhonghua Shuju 中华书局. 